\title{
Diversity of medicinal plants utilized by To Manui ethnic of Central Sulawesi, Indonesia
}

\author{
NUNING RAHMAWATI", FANIE INDRIAN MUSTOFA, SARI HARYANTI \\ Medicinal Plant and Traditional Medicine Research and Development Center. Jl. Raya Lawu 11, Tawangmangu, Karanganyar 57792, Central Java, \\ Indonesia. Tel./fax.: +62-271-697010, `email: nunrahmawati@gmail.com
}

Manuscript received: 9 October 2019. Revision accepted: 30 December 2019.

\begin{abstract}
Rahmawati N, Mustofa FI, Haryanti S. 2020. Diversity of medicinal plants utilized by To Manui ethnic of Central Sulawesi, Indonesia. Biodiversitas 21: 375-392. The present study reports the utilization of medicinal plants as medicines for the treatment of various diseases among the people of To Manui tribe in Central Sulawesi Province of Indonesia. Data collecting was conducted based on purposive random sampling to five selected traditional healers who fulfilled some inclusion criteria. The results showed as of 89 species of medicinal plants distributed in 50 families and 80 genera have been documented to have any pharmacological effects against 37 diseases and illnesses. Curcuma longa L. was determined as the most frequent medicinal plant used by traditional healers in To Manui for treating diabetes mellitus as well as after-birth treatment. However, conservation of some medicinal plants needs to be initiated in the study area especially Alstonia scholaris (L.) R. Br. as it is recognized in International Union for Conservation of Nature (IUCN) Red List as Least Concern (LC) of conservation status.
\end{abstract}

Keywords: Medicinal plants, To Manui ethnic, traditional healers

\section{INTRODUCTION}

Medicinal plants have been used by generations as traditional medicine for therapeutic uses for thousands of years in many parts of the world. As defined by World Health Organization (WHO), traditional medicine is a comprehensive term used to refer to both various forms of indigenous medicine and to traditional medicine systems such as traditional Chinese medicine, Indian Ayurveda, and Arabic Unani medicine (Anon 2019). Based on current information, $88 \%$ WHO member states have acknowledged their use of traditional medicine which corresponds to 170 member states (Anon 2019). According to WHO data, the developing countries populations utilized medicinal plants for treating ailments and diseases as of 65 to $80 \%$ and tend to quickly expand across the world (Megersa et al. 2019). Basic health research conducted by the Ministry of Health of Republic of Indonesia in 2018 reported that as many as $48 \%$ of Indonesia's population in all age categories used traditional health services in the form of traditional medicines (Anon 2019).

To Manui (derived from the word Manu means chicken) is one of the ethnic groups in Central Sulawesi Province located in Menui Islands Subdistrict, one of the exotic islands in Morowali District which is directly adjacent to the Banda Sea with a population of 13,316 in 2017. Menui Islands is the smallest sub-district $(4.07 \%$; $223.63 \mathrm{~km} 2$ ) of 9 sub-districts in Morowali District. Administratively, the west and south of Menui Islands are bordered by the Southeast Sulawesi Province, east of the Banda Sea and bordering the north by South Bungku and Banda sea (Anonim 2018b). Although administratively Menui included the Morowali District area, Menui's accessibility was closer to Kendari City, Southeast Sulawesi Province. With a distance of 99 nautical miles from the capital city of Morowali Subdistrict, it takes more than 14 hours to reach Menui Islands by ship and about 5 hours if taken from Kendari harbor. The topography of Menui islands is hilly with more than eighty percent of karst (limestone) land composition with limitation of clean water sources.

The health facilities available at Menui Kepulauan are a health center and sixteen rural polyclinics with a medical doctor, fifteen nursing staff, thirty-four midwifery staff, and pharmacy staff. While health facilities including hospitals, midwife practices, pharmacies, and drug stores are not yet available in Menui Islands sub-district (Anonim 2017). The limitations of health facilities availability and accessibility tend to encourage people to optimize natural resources in the area including the utilization of medicinal plants for self-medication. The most common reasons for the continued use of herbal medicine are that they are more accessible, more affordable, and more acceptable to local populations and can, therefore, be a tool to help in achieving universal health coverage (Zhang and Africa 2018)

The trend of medicinal plant utilization for treatment and prevention of disease is increasing over time. Local knowledge on the utilization of medicinal plants for health owned by communities and traditional healers is feared to be eroded and disappear when data collection and documentation in the form of databases were not available. Poverty is one of the main reasons for this rapid loss of indigenous knowledge systems as well as biodiversity. Poverty increases the pressure on natural resources and converts people from complex indigenous knowledge 
systems to simple and easy techniques such as chemical agriculture (Anon 2015). Manuel and Muller (2013) reported whether copyrights, patents, breeder's rights categorized as classic IP instruments are considered unsuitable to protect indigenous people's intellectual interests, both for technical reasons and often ideological reasons.

Therefore it is necessary to conduct research on documenting the utilization of medicinal plants and traditional knowledge of ethnomedicine in Central Sulawesi, especially within To Manui ethnic. This study is part of the national research on medicinal plant and Jammu (called Ristoja) carried out by National Institute Health Research and Development c.q. Medicinal Plant and Traditional Medicine Research and Development Center among 34 provinces in Indonesia including 405 ethnicities and involved 2,354 traditional healers as informants during 2012, 2015 and 2017.

\section{MATERIALS AND METHODS}

\section{Study area}

The study was carried out in Menui Islands sub-district of Morowali District, Central Sulawesi Province with the latitude and longitude-3.607323 and 123.149150 respectively (Figure 1). This sub-district is located 99 nautical miles further towards the capital city of Morowali District. Considering the location of this area directly surrounded by the ocean, the major source of livelihood was in fishery sector. The present study was taking place from August 23 to September 15 of 2015.

\section{Procedures}

\section{Data collecting}

Data collecting was carried out based on purposive sampling method. Data was collected through a survey based on structured questionnaire to five selected traditional healers. They are traditional healers who have the knowledge and skill of curing any ailments using medicinal plants, indigenous people of To Manui ethnic or acculturated people, the most well-known healer whom recognized by communities, and do practice of medication. The interviews were conducted by the research team with health education, anthropology and biology background.

The questionnaire was providing data on vernacular plant names, parts used, plant habitat, the dosage used, preparation method and route of administration. Furthermore, the traditional healers were also asked about the ailments treated, the definition of each ailment treated based on the perception of traditional healers and the symptoms that followed. The interviews were supplemented by direct observation as well as sample plant collection under the supervision of traditional healers. The plant voucher specimens were collected and deposited at Herbarium Tawangmanguensis of MPTMRDC. Ethical approval of this study was obtained from Health Research Ethics Commission of National Institute Health Research and Development, Ministry of Health.
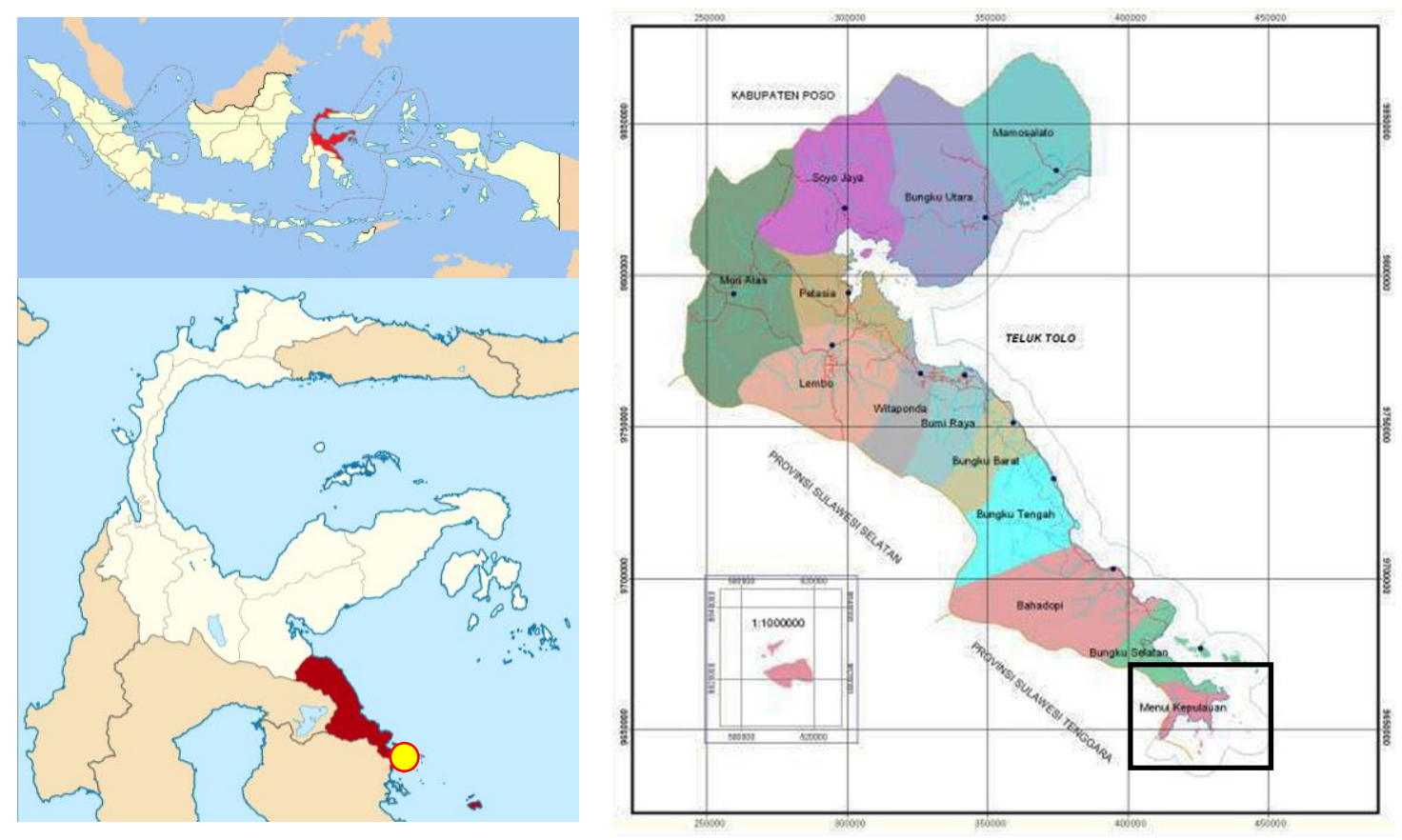

Figure 1. Location of To Manui ethnic in Menui Island sub-district of Morowali District, Central Sulawesi, Indonesia with the latitude and longitude-3.607323 and 123.149150 respectively. 


\section{Data analysis}

Quantification of data was conducted throughout the determination of use-value (UV) of each medicinal plant obtained. UV describes the use-value of a plant that is used as a medicine by traditional healers in To Manui ethnic of Central Sulawesi.

$$
U V=\mathrm{Ui} / \mathrm{n}
$$

(Ayyanar and Ignacimuthu 2011; Musa et al. 2011)

\section{Note:}

UV : Use Value;

$\mathrm{Ui}$ : The number of use reports cited by each informant for a given species

$\mathrm{n} \quad$ : The total number of informants interviewed

\section{RESULTS AND DISCUSSION}

\section{Medicinal plants used by traditional healers}

This current research addresses the existence of traditional indigenous knowledge in To Manui ethnic on utilizing medicinal plants for therapeutic uses. Therefore, it is urgently to preserve this indigenous knowledge on traditional medicines by proper documentation, identification of plant species, genera, family, parts used, herbal preparation, dosage and route of administration. The present study deals with 89 species of medicinal plants representing the local biodiversity of To Manui ethnic (Table 1). Among all species identified, there were several plants showing higher utilization rates, they are C.longa, $T$. catappa, A. scholaris, C. speciosus, H. alternate, A. flava, C. papaya, C. nucifera, J. curcas and M. citrifolia (Figure 2).

Traditional healers in To Manui ethnic used ten kinds of medicinal plant parts for many indications. Among them, leaf was recognized as the most frequently used (Figure 3) followed by herbaceous parts, rhizome, stem, stem bark, root, exudate, and other materials. From Table 1, it can be summarized the preparation steps of medicinal plant formula prescribed by traditional healers in order to cure any diseases. Firstly, the collecting of fresh materials rather than the dried one, continued with the sortation as well as washing and changing materials size by cutting, handcrushing, grinding, powdering, pounding, and mashing. The second one was the formula preparation. Each species has its own preparation way depending on administration route and medication goals both for preventing or curing any symptoms and diseases (Sambara et al. 2016). Route of administration and dosage determining became the last step of formula preparation by traditional healers. This last step was influenced by many factors as described by informant i.e kind of disease, patient number of age and the severity of disease.

Of eighty-nine medicinal plant species utilized by all informants distributed in 50 families, 80 genera and various vernacular names commonly used by traditional healers and local communities. The importance of a plant that is utilized in this study is stated by use-value. The use-value among all species are varying starting from 0.2 to 1.6 in which C. longa of Zingiberaceae family shown the highest use value (UV=1.6) followed by A. scholaris, T. catappa and $P$. betle with use-value as of $1.0,0.8$ and 0.8 respectively.

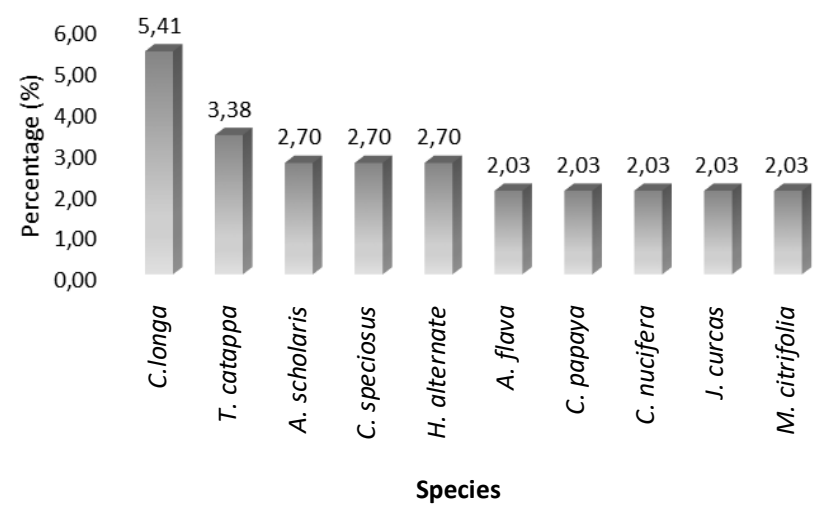

Figure 2. The top ten of medicinal plants used by traditional healers

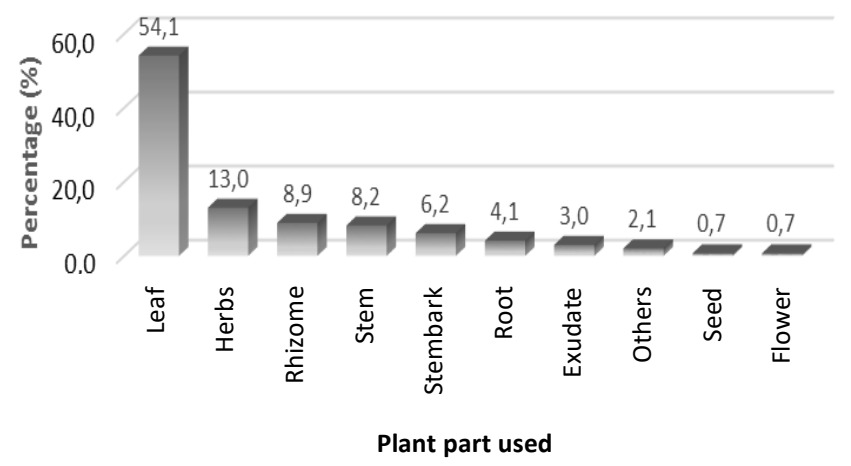

Figure 3. Percentage of plant parts used by traditional healers

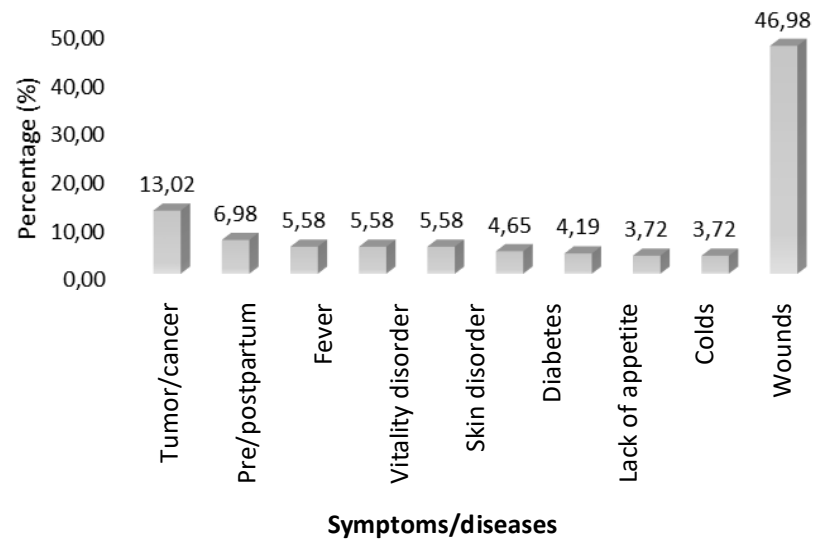

Figure 4. Percentage of traditional healers-treated diseases 
Table 1. Ethno-medicinal plants used in To Manui ethnic in Menui Islands, Morowali District, Central Sulawesi, Indonesia

\begin{tabular}{|c|c|c|c|c|c|c|c|}
\hline Family & Plant species & Local name & $\begin{array}{c}\text { Use } \\
\text { value }\end{array}$ & $\begin{array}{l}\text { Part } \\
\text { used }\end{array}$ & Ailment treated & Preparation and administration & Adverse reaction \\
\hline Annonaceae & Annona muricata $\mathrm{L}$. & Nangka, srikaya & 0.2 & Leaf & Hypertension & $\begin{array}{l}\text { Take } A \text {. muricata leaf, be washed, boiled and } \\
\text { drink as much as one glass a day for a week. }\end{array}$ & $\begin{array}{l}\text { Doses greater than } 5 \mathrm{~g} / \mathrm{kg} \text { of } \\
\text { aqueous extract might cause kidney } \\
\text { damage (Coria-Tellez et al. 2018) }\end{array}$ \\
\hline \multirow[t]{2}{*}{ Apocynaceae } & $\begin{array}{l}\text { Alstonia scholaris (L.) R. } \\
\mathrm{Br} \text { (LC/LR/Ic) }\end{array}$ & $\begin{array}{l}\text { Kompanga, } \\
\text { parasuli }\end{array}$ & 1.2 & $\begin{array}{l}\text { Cortex, } \\
\text { others }\end{array}$ & $\begin{array}{l}\text { Fever, } \\
\text { Tumor/Cancer, } \\
\text { Fertility disorder, } \\
\text { Cosmetics, heart } \\
\text { disease, malaria }\end{array}$ & $\begin{array}{l}\text { Take a half of a glass } A \text {. scholaris cortex, cut } \\
\text { into smaller size, be washed, boil with adequate } \\
\text { water, drink three times a day. Add Java chilli } \\
\text { and an egg yolk into formula before drinking. } \\
\text { Formula could also be ground into powder form } \\
\text { and apply topically. }\end{array}$ & $\begin{array}{l}\text { Long term treatment at dose } 500 \\
\text { and } 1000 \mathrm{mg} / \mathrm{kg} \text { bb showed toxic } \\
\text { effect on hepar (Bello et al. 2016) }\end{array}$ \\
\hline & $\begin{array}{l}\text { Voacanga foetida (Blume) } \\
\text { Rolfe }\end{array}$ & Kantudu & 0.2 & Exudate & Wounds healing & $\begin{array}{l}\text { Take some } V \text {. foetida stems, break and collect } \\
\text { the exudate than apply topically to the injury } \\
\text { skin as often as possible. }\end{array}$ & $\begin{array}{l}28 \text { days of aqueous extract } \\
\text { provision caused bodyweight } \\
\text { decrease of female Wistar rats (Igbe } \\
\text { et al. 2015) }\end{array}$ \\
\hline Araceae & $\begin{array}{l}\text { Aglaonema commutatum } \\
\text { Schott }\end{array}$ & $\begin{array}{l}\text { Ka asso-asso } \\
\text { tonuana }\end{array}$ & 0.2 & Leaf & Hemorrhoids & $\begin{array}{l}\text { Take one leaf of A. commutatum, cleaned, laid } \\
\text { down the leaf, put on hemorrhoid while being } \\
\text { pushed in. When taking this plant, do not let the } \\
\text { shadow of our body fall on the plant. }\end{array}$ & $\begin{array}{l}\text { The crude methanolic extract of } \\
\text { Aglaonema sp exhibit LD50 less } \\
\text { than } 1000 \mathrm{mg} / \mathrm{kg} \text { bb on brine } \\
\text { shrimp lethality test (Arnob 2011) }\end{array}$ \\
\hline Bromeliaceae & Ananas comosus (L.) Merr. & Nanasi & 0.2 & Fruits & $\begin{array}{l}\text { Pre and postpartum } \\
\text { treatments }\end{array}$ & $\begin{array}{l}\text { Take young A.comosus fruits, peeled and } \\
\text { shredded, filtered and then taken the juice to } \\
\text { drunk }\end{array}$ & $\begin{array}{l}\text { The aqueous leaf extract oral } \\
\text { provision did not induce any } \\
\text { toxicity in rats of acute and sub- } \\
\text { acute doses (Dutta and } \\
\text { Bhattacharyya 2013) }\end{array}$ \\
\hline Compositae & Bidens pilosa $\mathrm{L}$. & Sompa hoalu & 0.2 & Leaf & Sore eyes & $\begin{array}{l}\text { Take } B \text {. pilosa leaf and then cleaned, pounded } \\
\text { until smooth and then wrapped and squeezed } \\
\text { the juice, the juice/liquid produced, then } \\
\text { dropped on the eyes }\end{array}$ & $\begin{array}{l}4 \text { weeks oral administration of } \\
\text { aqueous extract exhibit significant } \\
\text { variation of ALT and creatinine } \\
(\mathrm{p}<0.001) \text { (Bopda et al. 2016) }\end{array}$ \\
\hline $\begin{array}{l}\text { Menispermacea } \\
\text { e }\end{array}$ & Arcangelisia flava (L.) Merr. & $\begin{array}{l}\text { Kamama, oeo } \\
\text { mokuni }\end{array}$ & 0.6 & Stems & $\begin{array}{l}\text { Wounds healing, } \\
\text { Jaundice, } \\
\text { Tumor/Cancer, } \\
\text { heart disease, } \\
\text { malaria }\end{array}$ & $\begin{array}{l}\text { Take } A \text {. flava leaf and stems then thinly sliced, } \\
\text { washing plant parts, boiled and drink of } 1 \text { cup } 3 \\
\text { times a day }\end{array}$ & $\begin{array}{l}\text { Oral administration of } 250,500 \text { and } \\
750 \mathrm{mg} / \mathrm{kg} \text { bw caused liver } \\
\text { congestion (Rachmawati and Ulfa } \\
\text { 2018) }\end{array}$ \\
\hline Myrtaceae & $\begin{array}{l}\text { Syzygium aqueum (Burm.f.) } \\
\text { Alston }\end{array}$ & Mongu padahu & 0.2 & Leaf & Antidiabetic & $\begin{array}{l}\text { Take the } S \text {. aqueum leaf, boil with enough } \\
\text { water, drink as much as } 2 \text { times a day, patients } \\
\text { should drink the concoction every week, } \\
\text { patients are advised to check the glucose blood } \\
\text { levels. }\end{array}$ & $\begin{array}{l}\text { Fatty liver and necrosis were } \\
\text { observed in female rats of ethanol } \\
\text { extract provision (Sumiwi et al. } \\
\text { 2019) }\end{array}$ \\
\hline
\end{tabular}


Take approximately 30 leaves of A. bilimbi, cleaned then boiled with enough water, the ingredients are taken 3 times a day.

$0.2 \quad$ Leaf Griff.

Hemigraphis alternata (Burm.f.) T.Anderson

Tonto memea, tontorada memea

Sericocalyx crispus (L.) Bremek

Amaranthaceae Achyranthes aspera L.

No name

Pupu

0.2 Leaf Gastritis

Anacardiaceae Anacardium occidentale L. Jampu

\section{Bouea macrophylla Griff. Ovola}

Lannea coromandelica

(Houtt.) Merr.

Keu Jawa, kayu

Jawa

$0.6 \quad$ Cortex

0.4 Leaf, cortex
Appetite booster

Fever, Cough,

Ulcer, Appetite

booster

Low back pain

Tonsillitis

Tumor/Cancer,

Heart disease,

Malaria

Fertility disorder,

Antidiabetic
Take G. pictum leaf, cleaned, pounded and pasted on the edge of the swollen part 3-4 times showed no hematological profile a day.

When taking this plant, do not let the shadow of Leaves extract of $H$. alternata up to our body fall on the plant. Take 5,7 or 9 leaves the dose of $4000 \mathrm{mg} / \mathrm{kg}$ in mice of $H$. alternata, cleaned then brewed with hot water or boiled, then cool and drink 3 times a day. Other ways to use by taking 5 leaves, cleaned and crushed by hand (kneaded) and then placed on the ulcer. Do it once a day and the effect will be seen on usage less than 1 week.

Take S. crispus and O. aristatus leaf, boil with Not yet available enough water, strain, wait for cold, then drink 1 cup twice a day.

Take all parts of the plant $A$. aspera except the Methanol extract of A. aspera up to roots, clean, boil with enough water, chill and dose of $500 \mathrm{mg} / \mathrm{kg}$ bb found to be drink twice a day. The effects will be seen after nontoxic on both acute and subdrinking the first time.

chronic toxicity test (Reddy and Kamble 2017)

Take leaf of C. asiaticum, Cordia sp., and $C$. verticillata, wash, finely mash all ingredients and distribute to the child's body after the child has finished showering twice a day.

Take A. occidentale leaf, clean, mash finely, take the juice and drink three times a day.

The material is washed clean, the stem is cut first so it is easy when boiling, then drink boiled water after getting cold.

Take the leaf of $L$. coromandelica and the roots The provision of hydroalcoholic of A. catechu which are cut into small pieces. extract of Lannea sp. up to dose All ingredients are boiled with enough water to $5000 \mathrm{mg} / \mathrm{kg}$ bb for 28 days did not boil. cool and drink one glass 2 times a dav. cause mortalitv and toxicitv signs methanol extract showed toxicity against BSLT with LD50 as of 243.331 and 507.838 respectively (Riris et al. 2018).

The administration of leaves extract of $500 \mathrm{mg} / \mathrm{kg}$ bb for 90 consecutive days caused reduction of white blood cell and platelet of Wistar rats (Wattanathorn et al. 2019) Not yet available 
Tonsilitis, Cough

Metroxylon sagu Rottb.

Haka rombia

Takung keu

Oreo, oreo

mohallo

Caricaceae

Carica papaya $\mathrm{L}$.

Pepaya

Combretaceae

Terminalia catappa $\mathrm{L}$.

0.2 Roots

$0.4 \quad$ Leaf

0.2 Leaf

0.6 Leaf

Rheumatics an

gout,

Hyperlipidemia

coster healing, Jaundice fruits, leaf disease

Appetite booster

Pre and postpartum Take the old yellowing leaf of C. papaya, the

treatments, Wounds rhizome of $C$. long $a$ and the fruit of $C$. citratus, after cold. When taking this plant, do not let the tox shadow of our body fall on the plant.

methanol leaves extracts provision the middle, mix the contents with water, boil $C$. of $200 \mathrm{mg} / \mathrm{kg}$ bw for 28 days nucifera with its throat for 10 minutes then showed no detectable alterations rubbed while reading the prayer life. Fruit can hematological, biochemical and only be taken on Friday. Another method is to histological parameters (Paul et al. take a $C$. nucifera fruit, beat it until the water comes out and drink one glass immediately 2 times a day. The effect will be seen in usage of less than 1 week.

M. sago herbs, (M. sago is used with roots edible coated from sago shown no growing upward), wash, boil with enough water, drink after cold.

Take the leaf of $C$. cujete and leaf $O$. aristatus wash and boil with enough water, drink one glass 3 times a day. antiseptic effect against Escherichia coli (Nisah 2017)

The provision of $50 \%$ ethanol extract caused toxic effect against Artemia salina during 24 hours of treatment (Sagrin et al. 2019)

Take Cordia $s p$ leaf, wash and mash finely, mix 90 consecutive daily oral provision with rice that has been finely ground into flour, of saline solution of extracts up to strain, and smear on the child's body after the dose of $400 \mathrm{mg} / \mathrm{kg}$ did not induce any toxicological effects on mice (Caparroz-assef et al. 2005)

Ethanol leaf extract up to dose 5

$\mathrm{g} / \mathrm{kg}$ bw administration increased

(Tarkang et al. 2012)

ds For anti-toxic, take the stembark and roots of T. $1100 \mathrm{ppm}$ administration of leaf catappa that are visible or grown on the ground, extract showed juvenile behavior cut into pieces, boil with enough water to boil, changes at 96 hours against cool and then drink three times a glass a day. Oreochromis niloticus (Yunus et For other uses, take T. catappa leaf, clean, fry, 2019) pound until formed like powder, add coconut oil to taste, ready for use on the skin or wound If the fruit is used, then take the fruit of $\mathrm{T}$.

catappa, crush the fruit skin, take the contents, boil with leaf of $\mathrm{C}$. papaya, drink three times a day as much as one glass.

Take A. lavenia herb, clean it, then brew with Not yet available

hot water, leave it for a few moments then the

water is put in / moved into the glass and taken one glass three times a day. 
Chromolaena odorata (L.) Komba-komba R.M.King \& H.Rob.

Vernonia amygdalina Delile klorovil

Convolvulaceae Ipomoea triloba L.

Luvuentahi

0.2 Roots

Costaceae Cheilocostus speciosus (J.Koenig) C.D.Specht

Tovu-tovu, palopalo

Crassulaceae

Bryophyllum pinnatum

(Lam.) Oken

Pomapu

$0.4 \quad$ Leaf

$0.8 \quad$ Stems

(2)

Rheumatics and

Hyperlipidemia diseases

Fever, Tonsillitis
Fever, Antidiabetic Take the leaf of B. pinnatum, boil, take the

$\begin{array}{lllll}\text { Cyperaceae } & \text { Scleria sp. } & \text { Kila-kilala } & 0.2 & \text { Fruits }\end{array}$

Scleria sumatrensis Retz. Kila-kilala

0.2 Leaf
Take the leaf of $A$. conyzoides, clean, mash finely, add one glass of water and use it to be applied to the stomach and chest of the sick child. When taking this plant, do not let the shadow of our body fall on the plant.

Take $B$. riparia leaf, crush and paste on the baby's umbilical cord to dry quickly, use as often as possible until the umbilical cord is loose, usually used for three to four days.

Take the leaf of C. odorata, the number of it to the body. (Paulose et al. 2016)

$V$. amygdalina and $O$. aristatus,

wash and boil with enough water, drink 3 cups a day.

Take I. triloba roots, then wrap it around the patient's hand.

Take the stem of $C$. speciosus, split it in half and take them inside, grated and add enough water and drink the water. Another way is to brew the inside of the stem that has been taken

with hot water, let stand a few minutes then drink three times a day as one glass. When taking this plant, do not let the shadow of our body fall on the plant. water and drink after it is cold. Another way is $5000 \mathrm{mg} / \mathrm{kg}$ bb exhibied to dose to finely pulverize the leaf and put them directly mortality and hematological on the patient's body. When taking this plant, do alterations against Sprague-Dawley not let the shadow of our body fall on the plant.

28 days provision of $500 \mathrm{mg} / \mathrm{kg}$ bw lowering urea levels of Wistar rats (Diallo et al. 2010a)

Phenolics compound in this plant might contribute to hemostatic

weight gain in treated mice

Aqueous extract administration hemoglobin against African catfish (Olowolafe and Mo 2018)

Not yet available

Acute toxicity test showed no toxicology signs ((Specht et al. 2014)

Take the Scleria $s p$ fruit, mash and paste it on Not yet available the ulcer. Sticking is done around the ulcer twice a day. The effect will be seen at less than 1 week.

Take $S$. sumatrensis leaf, clean, soak in warm $\quad$ Not yet available water for five minutes. Immersion water is distributed to the injured body part. When taking this plant, do not let the shadow of our body fall on the plant. properties (Huang et al. 2010) tend to decrease red blood cell and 


\begin{tabular}{|c|c|c|c|c|c|c|c|}
\hline \multirow[t]{2}{*}{ Davalliaceae } & $\begin{array}{l}\text { Nephrolepis acutifolia } \\
\text { (Desv.) H. Christ }\end{array}$ & Ato-ato & 0.2 & Others & Diarrhea & $\begin{array}{l}\text { Take young leaf of } N \text {. acutifolia, clean, boil } \\
\text { with water, drink } 1 \text { cup of boiled water three } \\
\text { times a day. }\end{array}$ & Not yet available \\
\hline & $\begin{array}{l}\text { Nephrolepis biserrata (Sw.) } \\
\text { Schott }\end{array}$ & Ato-ato & 0.4 & $\begin{array}{l}\text { Leaf, } \\
\text { herbs }\end{array}$ & $\begin{array}{l}\text { Wounds healing, } \\
\text { Pre and postpartum } \\
\text { treatments }\end{array}$ & $\begin{array}{l}\text { Take the curved } N \text {. bisserata young leaf, mash } \\
\text { and apply on the wound. For Pre and } \\
\text { postpartum treatments, take herbs of } N \text {. } \\
\text { bisserata with Tamarindus indica, brew with } \\
\text { hot water, drink after cold. }\end{array}$ & Not yet available \\
\hline \multirow[t]{3}{*}{ Euphorbiaceae } & Euphorbia hirta L. & $\begin{array}{l}\text { Pulu-pulu tumpu, } \\
\text { pulum-pulu } \\
\text { tumpu inia }\end{array}$ & 0.4 & $\begin{array}{l}\text { Exudate, } \\
\text { herbs }\end{array}$ & $\begin{array}{l}\text { Wounds healing, } \\
\text { Appendicitis }\end{array}$ & $\begin{array}{l}\text { Take } E \text {. hirta stems, break it and take the sap } \\
\text { and apply directly to the wound. Other uses by } \\
\text { taking } E \text {. hirta herbs, clean, boil with enough } \\
\text { water, chill and, drink three glasses a day. }\end{array}$ & $\begin{array}{l}\text { Acute and sub-acute toxicity test } \\
\text { revealed the giving of methanol } \\
\text { extract caused no toxicological } \\
\text { signs against SD rats (Ping et al. } \\
\text { 2013) }\end{array}$ \\
\hline & Jatropha curcas L. & Beau dava & 0.6 & $\begin{array}{l}\text { Cortex, } \\
\text { leaf, } \\
\text { exudate }\end{array}$ & $\begin{array}{l}\text { Cough, } \\
\text { Hemorrhoid, } \\
\text { Gastritis }\end{array}$ & $\begin{array}{l}\text { Take } J . \text { curcas stembarks, boil with enough } \\
\text { water, wait until cool. For serving, add egg } \\
\text { yolks. Other uses by taking five leaves of } J \text {. } \\
\text { curcas, cleaning and reheating, after that the } \\
\text { leaf is arranged and used to wrap the river stone } \\
\text { to be placed on hemorrhoid. To treat gastritis, } \\
\text { take the sap of } J \text {. curcas sap and drink it. }\end{array}$ & $\begin{array}{l}\text { Case study reported the seed to } \\
\text { consume of J. curcas caused } \\
\text { vomiting and diarrhea (Shah } \\
\text { 2010). }\end{array}$ \\
\hline & $\begin{array}{l}\text { Macaranga peltata (Roxb.) } \\
\text { Müll.Arg. }\end{array}$ & Soso nana & 0.2 & Leaf & Ulcer & $\begin{array}{l}\text { Take } M \text {. peltata leaf with the amount depending } \\
\text { on the size of the ulcer. The leaf is pounded and } \\
\text { pasted on or around the ulcer. The attachment is } \\
\text { not comprehensive on the ulcer only at the } \\
\text { edge. }\end{array}$ & $\begin{array}{l}\text { Leaf and stem bark extract of } \mathrm{M} \text {. } \\
\text { peltata exhibited cytotoxic effect } \\
\text { against liver cancer cell line } \\
\text { (Verma et al. 2009) }\end{array}$ \\
\hline Goodeniaceae & $\begin{array}{l}\text { Scaevola taccada (Gaertn.) } \\
\text { Roxb. }\end{array}$ & Pado-pado & 0.6 & $\begin{array}{l}\text { Stems, } \\
\text { leaf, fruits }\end{array}$ & $\begin{array}{l}\text { Anti-toxic, Fever, } \\
\text { Sore eyes }\end{array}$ & $\begin{array}{l}\text { Take leaf and stems } S \text {. taccada by dredged then } \\
\text { boiled with water until it changes color. Potions } \\
\text { taken three times a day. Drink in warm or cold } \\
\text { conditions. Another way is by taking the fruit } \\
\text { juices and drop it on the affected eye. }\end{array}$ & $\begin{array}{l}\text { n-butanol fraction showed toxic } \\
\text { effect against Artemia salina with } \\
\text { LC50 as of } 12.16 \mu \mathrm{g} / \mathrm{ml} \text { (Santi and } \\
\text { Nurbaezurah 2013) }\end{array}$ \\
\hline \multirow[t]{2}{*}{ Lamiaceae } & Hyptis capitata Jacq. & Komba kau & 0.2 & Leaf & Flu & $\begin{array}{l}\text { Take the leaf of } H \text {. capitata, mash finely, add a } \\
\text { little water then take the juice and drop it into } \\
\text { the nose which is clogged three times a day. } \\
\text { When taking this plant, don't let the body fall on } \\
\text { the plant. }\end{array}$ & $\begin{array}{l}\text { Hyptis sp. leaves infusion shown no } \\
\text { toxicity signs against Drosophila } \\
\text { melanogaster and Artemia salina } \\
\text { (Bezerra et al. 2017) }\end{array}$ \\
\hline & $\begin{array}{l}\text { Orthosiphon aristatus (Bl.) } \\
\text { Miq. }\end{array}$ & Kumis kucing & 0.8 & $\begin{array}{l}\text { Leaf, } \\
\text { herbs }\end{array}$ & $\begin{array}{l}\text { Rheumatics and } \\
\text { gout, } \\
\text { Hyperlipidemia, } \\
\text { Appendicitis, Low } \\
\text { back pain }\end{array}$ & $\begin{array}{l}\text { Take the leaf of } O . \text { aristatus and } V . \text { amygdalina, } \\
\text { wash, boil with enough water, drink three } \\
\text { glasses a day. }\end{array}$ & $\begin{array}{l}\text { Standardized ethanol extract of } O \text {. } \\
\text { aristatus decrease AST and ALT of } \\
\text { athymic nude mice model (Yehya } \\
\text { et al. 2019) }\end{array}$ \\
\hline Fabaceae & $\begin{array}{l}\text { Flemingia macrophylla } \\
\text { (Willd.) Merr. }\end{array}$ & Polita & 0.2 & Leaf & Ulcer & $\begin{array}{l}\text { Take } F . \text { macrophylla leaf, wash, lay and then } \\
\text { apply to the ulcer. }\end{array}$ & $\begin{array}{l}\text { Root ethanol extract up to dose } 600 \\
\mathrm{mg} / \mathrm{kg} \text { bw prolonged sleeping time } \\
\text { of pentobarbitone effect (Gahlot et } \\
\text { al. 2013) }\end{array}$ \\
\hline
\end{tabular}


Tumor/Cancer, Heart disease Malaria

0.2 Cortex Fever

Flemingia strobilifera (L.) Polita W.T.Aiton

Senna alata (L.) Roxb. Tamba palang singa, tamba palan singa

Tamarindus indica $\mathrm{L}$.

Sampalu/asam Jawa

Tamarindus sp.

Asam Jawa

Vigna marina (Burm.) Merr. Komba-komba

Leaf

Linderniaceae Picria fel-terrae Lour.

Bantiala

$0.2 \quad$ Herbs

Low back pain

Skin disease, Ant

toxic, antidiabetic

$$
\text { roots }
$$

0.2 Fruits

0.2 Fruits

Pre and postp

treatments

Tonsillitis

0.2 Leaf Skin disease

Malvaceae

Gossypium arboreum L.

Kapa

Hibiscus tilliaceus $\mathrm{L}$.

Bontu

Constipation

Sida rhombifolia L.

Kukuni
0.2 Herbs
Take A. precatorius herbs, cut into smaller parts Orally consume of A. precatorius to make it easier for boiling, washing, boiling, seed induced drowsiness,

drinking after cold.

staggering gait, coma, convulsion and death in severe cases (Kafle et al. 2018)

Take $F$. strobilifera stems, scrape and take the Roots ethanol and ethyl acetate bark, brew with hot water, drink one glass twice fraction showed depressant effect a day.

on central nervous system

(Mahajon 2019)

Not yet available

ata leaf, clean, add salt, then

directly rubbed on the skin, do it twice a day and the effect will be seen on the third day of use. The other way is to take the root of $S$. alata, wash it, boil it with enough water to boil, chill and drink 2 times a day as glass and the effect will be seen in use less than 1 week.

$\begin{array}{ll}\text { Pre and postpartum } & \text { Take } T \text {. indica fruits, add it with hot water, stir, } \\ \text { treatments } & \text { strain, and drink by mother after giving birth. }\end{array}$

Long-term used (6 months) of $T$. indica pulps induce no hematology and blood biochemistry parameters alterations (Iskandar et al. 2017)

Take one or more $T$. indica fruits, add with hot water, stir, strain, then drink it to the mother after giving birth. The concoction is taken only once after giving birth.

Take leaf $V$. marina, wash, mash, take the juice Acute toxicity test showed no and drink once a day.

mortality found up to dose 1000 $\mathrm{mg} / \mathrm{kg}$ bw of Vigna sp (Battu et al. 2011)

Take one or more (the amount must be odd) $P . \quad 500$ and $1000 \mathrm{mg} / \mathrm{kg}$ bw ethanol fel-terrae fruits, clean, boil, drink 3 times a day. extract administration of sample Effects begin to appear after the use of the fifth cause reversible toxicity on subday. chronic toxicity (Harahap et al. 2018)

Take the leaf of G. arboreum, clean it, then rub Gossypol induced toxic effects that it immediately on the affected skin.

were the impairment of male and female reproduction (Gadelha et al. 2014)

Take $H$. tiliaceus leaf, clean, boil with enough The ethanol leaf and bark extract water to boil, cool, drink 3 times a day as much lowering onset as well as total as 1 cup and the effect will be seen in use less sleeping time (Awal et al. 2016) than 1 week.

Tumor/Cancer When taking this plant, don't let the body fall on Water root extract up to dose 5000 the plant $\mathrm{mg} / \mathrm{kg}$ bw did not cause acute and sub-chronic toxicity of rats (Sireeratawong et al. 2008) 
Take $U$. lobata leaf, clean, mash until the juice comes out, drop it on the affected part of the body 3 times a day. When taking this plant, don't let the body fall on the plant

Nene

\section{G.Forst.) K.Schum \\ Marantaceae}

Moraceae

Ficus septica Burm.f.

Libonu

Ficus sp.

Taimanu

Moringaceae

Moringa oleifera Lam.

Inahung keu

Musaceae

Musa $\times$ paradisiaca $\mathrm{L}$.

Pohon pisang,

punti manuru,

punti

Myristicaceae

Myristica fragrans Houtt.

Pala

Psidium guajava $\mathrm{L}$.

Jambu biji

Passifloraceae Passiflora foetida L.
Gola-gola
0.2 Herbs Tonsillitis

$0.2 \quad$ Leaf

Fever

Leaf

Dysentery

$0.2 \quad$ Leaf

Sore eyes
$0.2 \quad$ Leaf

Diarrhea

0.6 stems, Antidiabetic

fruits, leaf Gastritis, Stroke, Paralyzed

\section{Cough}

Antidiabetic, Pre and postpartum treatments

$0.4 \quad$ Leaf
Take the $D$. canniformis herbs, clean it, cut it

into smaller portions, boil, after boiling, waiting

for cold and drink three times a day.

Take one or more F. septica leaf (depending on Methanol stem extracts of $2 \mathrm{mg} / \mathrm{ml}$ the surface area of the child's body), leaf on a of $F$. septica induced moderate clean cloth and immediately attach to the child's damage to the duck embryo livers body. If it has begun to wilt, the leaf is replaced (Gamallo and Gallego 2017) with new leaf and so on until the heat of the

child begins to fall.

Take the leaf of Ficus sp, clean, boil with enough water to boil, chill and drink one glass three times a day

\section{Methanol leaf extract lowering}

VEBs and the incidence and duration of Rev VF (Allahyari et al. 2014)

Take one handful of $M$. oleifera leaf, clean it, Methanol leaf and seed extract mash it until smooth, put it in a dish and add it administration up to dose of 1000 with one glass of water. Then the eyes are soaked by directing the face into the dish.

$\mathrm{mg} / \mathrm{kg}$ bw significantly increase neutrophil, white blood cell and platelet (Olayemi et al. 2016)

Take three old $M$. x paradisiaca leaf and 3 rhizome $\mathrm{C}$. longa, clean, grate and mix with brown sugar then mash

Aqueous fermented extract dose

$5000 \mathrm{mg} / \mathrm{kg}$ bw induced significant alteration on white blood cells, eosinophil, platelets, urea, creatinine, alanine aminotransferase and high-density lipoprotein levels of rats (Ugbogu et al. 2018)

Take $M$. fragrans fruits, clean and eat it three times a day to deal with itching in the throat. The effect will be seen in usage of less than 1 week.

Take young $P$. guajava leaf, clean, boil with enough water and drink one glass three times a day. When taking this plant, don't let the body fall on the plan

Take $P$. foetida leaf, boil with enough water, drink during the puerperium.
Consume as of $5 \mathrm{~g}$ of ground nutmeg shown to cause

hallucinogenic effects (Rahman et al. 2015)

Ethanolic leaves extract provision of $P$. guajava at dose of $750 \mathrm{mg} / \mathrm{kg}$ bw for 28 days caused soft and mucous feces, and 20-40\% animal death (Utami et al. 2018)

Th provision of the extract of 1600 $\mathrm{mg} / \mathrm{kg}$ bw for 6 months induced fatty infiltration in the cortex of adrenal glands of Wistar rats (Chivapat et al. 2011) 
Phyllanthaceae Breynia oblongifolia (Müll.Arg.)

Breynia sp.

Hilale

Leaf

Phyllanthus niruri L.

Pae-pae

Phyllanthus urinaria $\mathrm{L}$.

Evo bokori

Piperaceae

Peperomia pellucida (L.)
Kunth

Evo mongura

Piper betle L.

Levenseua

Piper nigrum L.

Rica Jawa

Piper sarmentosum Roxb. Luasi

Cymbopogon citratus (DC.) Loyale Stapf

Imperata cylindrica $(\mathrm{L}$. Rausch.
Alang-alang, le
Leaf

$0.6 \quad \mathrm{Bij}$

\section{Tumor/Cancer}

Tumor/Cancer, Fertility disorder. Sore eyes, heart disease, malaria

Tumor/Cancer,

Heart disease,

Malaria

Flu

0.4 Roots, herbs treatments heart disease, malaria

\section{malaria}

Cough, Theart disea

malaria

Pre and postpartum train and drink to the mother after giving birth.

\section{P. pellucida herbs, clean, boil with three} cups of water, bring to the boil until the leaves had depres $P$. pellucida remaining 1.5 cups, cool and drink three times a mice (Khan et al. 2008) day.

Take $P$. betle leaf, $L$. coromandelica stems and $P$. betle ethanol extract showed no roots of $A$. catechu, wash, cut into smaller toxicity against brine shrimps pieces, boil all ingredients with enough water to (Sequete et al. 2016)

boil, cool and drink. Other ways to use the leaf

of P. betle, clean, mash, place it on a plate and add water, for the treatment of the eyes soaked into the liquid (plate) and open, soak for about 5

minutes.
Take $P$. nigrum seeds, wash, mash, brew with hot water, strain, drink.

P. nigrum administration caused architectural distortions as evident in the kidneys, liver and testes (Omorodion and Ajanwachuku 2018)

Take leaf of $P$. sarmentosum and $C$. longa, mash until smooth, add a little water, the extract obtained is deposited into the nose.

Pre and postpartum Take as many as five C. citratus, one leaf of old Chemical fractions of C. citratus treatments, $\quad$ C. papaya and three Rhizome of C. longa, wash indicated to possess cytotoxic and Tumor/Cancer, all ingredients, boil, strain, chill, drink. When genotoxic properties (Fuentes-Leon taking this plant, plant. disorders boil with enough water, strain, cool, drink

\section{Aqueous extract of I. cylindrica} does not cause acute and subchronic toxicities in rats (Chunlaratthanaphorn et al. 2014) 
Polypodiaceae Drynaria quercifolia (L.) J. Kokapi Sm.

Phymatosorus scolopendria Kondovatu (Burm f) Pic Serm.

Rubiaceae Morinda citrifolia $\mathrm{L}$.

0.2 Rhizome Tumor/Cancer

0.4 Leaf, Vitality disorder, cortex Fever

Rutaceae

Citrus aurantiifolia (Christm.) Swingle

Susua ntomi

0.2 Leaf

Solanaceae

Physalis peruviana $\mathrm{L}$.

Bengki-bengki

$0.2 \quad$ Herbs

Urticaceae

Laported Chew

Karu karu mansi

0.2

Stems

Verbenaceae
Lantana camara $\mathrm{L}$.
Katange
0.2 Leaf
Take young $Z$. Mays fruits, grate, add a little water, drink once a day. The effect will be seen in usage of less than 1 week.

Tonsillitis, Pre postpartum treatments

Tumor/Cancer

Hypertension

Fever

Take

r, chill, drink 2 times a glass a day

Effects begin to appear on the use of the second

day. You can also take one of the herbs $P$.

paniculata, $C$. longa rhizome as many as 3

segments or more, then grated. Each plant is

then cleaned and brewed with hot water.

Take part in the white stem of D. quercifolia water will be purplish, then the affected eye is immersed in the solution.

dose $2000 \mathrm{mg} / \mathrm{kg}$ bw found to be Take the leaf of C. aurantifolia dry, clean, boil Not yet available

with enough water to boil, cool then drink

Take the leaf of $M$. citrifolia , cleaned and immediately placed on the child's body. The

frequency of usage depends on the level of wilt. If the leave got wilt, then replaced immediately with the new leave until the child's bioche heat drops. Another way is to boil leaf with enough water and drink 2 cups a day.

Take the dry eaves of $C$. aurantifolia, clean, boil with enough water, wait until cold then drink.

Take $P$. peruviana herbs, clean, boil with enough water, drink twice a day in the morning and evening.

Take $L$. interrupta leaf, clean, brew with hot water and drink the water. When taking this plant, don't let our bodies fall on the plant.

Hypertension

Corn silk extract provision up to $2000 \mathrm{mg} / \mathrm{kg}$ bw reporte toxicity signs (Ha et al. 2018)

P. paniculata hydroalcoholic extract produced an antidepressant-

Methanol leaves extract up to dose $2000 \mathrm{mg} / \mathrm{kg}$ bw for 28 days showed no significant changes in body weight, hematological and

$$
\text { et al. 2015) }
$$

Root aqueous extract administration up to dose 1200 $\mathrm{mg} / \mathrm{kg}$ bw/day for 90 days exhibited no signs of abnormalities (Chunlaratthanaphorn et al. 2007) Lyophilized fruit juice of $P$. peruviana was known to induce cardiac toxicity only at high doses and in male gender (Perk et al. 2013)

The ethanol extract of Laportea sp. showed toxicity against BSLT with LC50 as of $285 \mu \mathrm{g} / \mathrm{mL}$ Simaremare et al. 2018)

Take $L$. camara and chlorophyll leaf, clean, boil Root extract was shown to have with enough water, chill and drink one glass three times a day 
Stachytarpheta jamaicensis Kambabula

\section{(L.) Vahl}

Vitaceae

Cissus verticillata $(\mathrm{L}$.)

Nicolson \& C.E.Jarvis

Terevu

$0.2 \quad$ Leaf

Lo'ia, liku

Curcuma longa $\mathrm{L}$

Kunyit, kuni bula

1.6

Rhizome

$$
\text { and postpartum }
$$$$
\text { treatments, Flu }
$$

Antidiabetic,

Wounds healing

0.4 Rhizome Low back pain, Pre

and postpartum

treatments

reatments, Flu

Zingiber officinale Roscoe

Lo' iale, lo'ia

Zingiber zerumbet (L.)
Bangule
0.6 Herbs, Stroke, Paralyzed, rhizome Vitality disorders
Take the leaf of $S$.jamaicensis, wash, squeeze Leaves powder up to dose $75 \mathrm{~g} / \mathrm{kg}$ the leaf using hands and attach them directly to bw caused mild histopathological the injured part.

lesion of kidney, liver and lung (JE et al. 2006)

Take leaf of $C$. verticillata, mix with leaf of $C$. Hydroalcoholic Cissus sp. leaves asiaticum. All ingredients are finely grounded extract up to dose of $40.5 \mathrm{mg} / \mathrm{kg}$ bw and distributed to the child's body after bathing of chronic toxicity showed twice a day.

reversible increase in albumin, erythrocytes, and hemoglobin of Wistar rats (Diniz et al. 2018)

Take leaf of $L$. indica and Rhizome C. longa, Leaf ethanol extract showed cleaned, mashed until smooth, apply to the wound.

cytotoxic compared to vincristine cytotoxic compared to vincristin
sulfate (Rahman et al. 2013) Intraperitoneal administration of take the juice, add the chicken egg yolk, sugar hexane extract dose of $2000 \mathrm{mg} / \mathrm{kg}$ and honey, stir and ready to drink once a day. bw was highly toxic against Wistar

$\begin{array}{ll}\text { and honey, stir and ready to drink once a day. } & \text { bw was highly toxic against Wist } \\ \text { The effect will be seen on day } 2 . & \text { rats (Karunarathne et al. 2018) }\end{array}$

Six months provision of 2,5 and 5 mix it with L.indica leaf, boil with water and $\quad \mathrm{gr} / \mathrm{kg}$ bw/day turmeric implied on drink it every day for 40 days after giving birth. body weight, food consumption,

When taking this plant, don't let our bodies fall clinical signs, blood chemistry, on the plant.

hematological and

histopathological changes

(Sittisomwong et al. n.d.)

Long-term use of root oil extract

indicate to cause some unexpected adverse event like oxidative stress (Idang et al. 2019)

Rhizome ethanol extract use for 28 days showing no toxicity signs on Wistar rats (Chang et al. 2012) 
Traditional healers utilized the cortex and other parts of A. scholaris for treating fever, tumor/cancer, fertility disorder, cosmetics, heart disease, and malaria with peroral route of administration. For T. catappa, almost all plant parts (leaf, fruits, cortex, root) were used for treating such conditions as anti-toxic, wounds healing and solving skin disease with vary of provision ways. While $P$. betle was generally collected its leaves in order to resolve cases of tumor/cancer, fertility disorder, sore eyes, heart disease as well as malaria. Z. zerumbet, $C$. verticillata, D. quercifolia, $Z$. mays, and some other species exhibited to have the lowest of use-value as of 0.2 . The species revealing the higher index of use-value means having a greater potency for utilizing by communities (Mayo et al. 2015).

Table 1 show that there are many plants used for only one indicator and the other plants utilized to overcome some symptoms of the disease. The percentage ratio between the single and multiple usage plants was slightly different, whereas 52 of 89 species of plants were used by traditional healers to treat one type of ailment while the remains plants revealed more than one indication.

\section{The treated diseases}

The phytotherapy traditional knowledge of this ethnic provides excellent results in the treatment of 37 different types of ailments and diseases in humans (Table 1). The choice of therapy was influenced by educational level and having health insurance (health insurance does not cover traditional treatment). The main reasons for attending a traditional healer were linked to educational level, the type of dwelling and the patients residence place (Agbor and Naidoo 2016). These ailments were complained of by the patients, the diagnosis was made by traditional healers and submitted treatment solutions to traditional healers in the To Manui ethnic. Of all the types of diseases, it is known as many as ten types of diseases that are the most common and most widely complained by patients including tumor/cancer, pre, and postpartum treatments, fever, vitality disorder, skin disorder, diabetes, lack of appetite, colds, wounds and other disease groups as shown in Figure 4.

\section{Discussion}

This study demonstrated the importance of well documenting of indigenous local knowledge on medicinal plants and traditional medicine utilized and locally distributed in Central Sulawesi Province especially in To Manui ethnic. Medicinal plants are vital source to combat human diseases and play an important role in healing many serious diseases all over the world due to the presence of active phytochemical compounds (Sharma 2017). The utilization of traditional medicine tends to be more profitable because it is relatively more easily available, cheaper and the raw material can be planted in the yard both for decorate garden and healing usage (Tambaru 2016).

From 89 species of medicinal plants used by traditional healers in To Manui ethnic and relevance with previous research (Subositi and Wahyono 2019), it was reported whether Curcuma longa $\mathrm{L}$ is the most widely used medicinal plant and has the highest use value index (1.6) (as shown in Figure 1 and Table 1). The species with the highest use value index are actually great importance to the local communities in the case of native species and also very pivotal to be one of the considerations in local biological conservation strategies (Mayo et al. 2015). $C$. longa is used by traditional healers in To Manui ethnic to treat various symptoms/diseases such as diabetes, pre, and post-natal care and flu/colds. Curcumin contained in $C$. longa and most species of the Zingiberaceae family are the main components responsible for various pharmacological effects including antidiabetic, anticancer, antiinflammatory, antimicrobial, antifungal, anti-HIV and as hepato-and nephroprotector (Kurapati and Samikkannu 2012; Ayyadurai et al. 2013; Rafieian-Kopaei et al. 2014; Hamidpour et al. n.d.; Schmidt et al. 2015; Shukla et al. 2016). Olatunde et al. (2014) reported oral administration of water extract C. longa $200 \mathrm{mg} / \mathrm{kg}$ bw for 28 days had an antihyperglycemic effect in diabetic rats induced by alloxan. The rhizome of $C$. longa positively exhibited the mechanism of maintaining blood glucose levels of alloxaninduced hyperglycemic rats (Aizman et al. 2014). When compared to water and n-hexane extract, the provision of C. longa methanol extract at dose of $400 \mathrm{mg} / \mathrm{kg}$ bw for 28 days revealed a higher hypoglycemic effect (Mohammed 2017). A decrease in blood sugar levels after administration of curcumin may be caused by a lowering in the rate of absorption of carbohydrates due to the $\mathrm{Na}^{+}$glucose cotransporter. The activation of $\mathrm{Na}^{+}$glucose co-transporter may result in an increase in glucose absorption rate of hyperglycemic rats compared to the normal one (Aizman et al. 2014).

The most frequently used plant parts for treatment by traditional healers in To Manui ethnic is leaf followed by herbaceous parts and rhizome, while flower is recognized as the least common used plant part. This result is in agreement with the previous study conducted by (Dhal et al. 2015) wheres leaf, root, bark, herbaceous parts and seed are the five highest utilization parts of plants by traditional healers and people in Odisha, India. A similar result was also reported by Karthiyayini 2012; Mabel et al. 2016; Sambara et al. 2016; Mustofa and Rahmawati 2018; Town 2018) in which leaf was the highest frequently plant part used. When compared to other plant parts, leaf is the easiest part to obtain and to be managed (Sambara et al. 2016). Leaf becomes the accumulation place of organic compounds of photosynthesis which has the possibility of curing a disease (Tambaru et al. 2016). However, (Ngarivhume et al. 2015) reported that root and bark were the most widely used plant part by healers in Zimbabwe, especially for treatment and prevention of malaria. Nevertheless, the use of both types of plant parts in a sustainable manner will disrupt the survival of the plant itself.

A tumor/cancer was reported as the most frequent disease treated by traditional healers in To Menui ethnic. In this current study, tumor/ cancer is defined as abnormal lumps in the body characterized by solid consistency and has possibility to develop into malignancy. In modern medicine, cancer is defined as a group of diseases 
characterized by the uncontrolled growth and spread of abnormal cells which can result in death (Anon 2018a). The latest World Health Organization data showed there were 18.1 million new cases and 9.6 million deaths caused by cancer whereas lung cancer, breast cancer, and colorectal cancer were the major cancer types among 2018. World cancer prevalence for the last five years (2014-2018) estimated at 43.8 million (Anon 2018). Different data came from the Health Department of Morowali District whereas diarrhea was reported as the most common disease in Menui Islands among 2017 with the case number of 369 (Anon 2018). Some medicinal plants are reported to have antidiarrheal activity, one of them is Curcuma longa L. It has a correlation with this current research whereas $C$. longa was declared as the most widely medicinal plant used by traditional healers in To Manui ethnic. Previous research showed aqueous extracts of $C$. longa with a dose of $1000 \mathrm{mg} / \mathrm{kg}$ bw indicated to have potent antidiarrhoeal activity compared to standard drug and proven to have no toxic effect (Krishna et al. 2019).

Among fifty families documented from this present study, Asteraceae (formerly called Compositae) is the most prominent plant family used by traditional healers in To Manui ethnic. (Megersa et al. 2019) also reported Asteraceae as the leading family followed by Fabaceae on treating toothache in Ethiopia. This is slightly different from the study results conducted by (Yulia et al. 2017) in which Lamiaceae was determined as the most widely plant family used by the Topo Uma ethnic group in Sigi District, Central Sulawesi. On the other hand, another study highlighted whether Fabaceae was the most abundant family in Kurdistan, Iraq (Ahmed 2016). Sciences et al. (2008) mentioned several genera such as Aster, Helianthus, Chrysanthemum and Tagetes from Asteraceae family were potential to be developed as a source of medicinal ingredients. A. conyzoides $(\mathrm{UV}=0.4)$, one of Asteraceae family species was the most frequently used by traditional healers in To Manui ethnic to treat fever, flu, and colds. (Masudur et al. 2013) reported A. conyzoides was exhibited to have antioxidant and analgesic activity. All plant parts of A. conyzoides reported containing alkaloid, flavonoids, saponins, chalcones, tannins, saponins and phenols compounds (Amadi et al. 2012). Antioxidant activity of a plant is correlated with its flavonoids content, types of flavonoids, chemical structures and $\mathrm{OH}$ functional groups position of in these molecules. Many flavonoids are the active components of medicinal plants which show any pharmacological activities (Ogbalu and Williams 2014). The ability of proton or electron donors to free radicals, chelating ions, inhibition of free radical-forming enzymes, interactions with mitochondria and changes in gene expression are some factors affecting the antioxidant activity of a compound (Bessada et al. 2015).

The conservation status of all species documented was examined at The IUCN Red List of Threatened Species and it was known that Alstonia scholaris (L.) R. Br. is the only species included in the list with the least concern or lower risk category (LC/ LR/ Ic). With the main chemical compositions of alkaloids, iridoids, coumarin, flavonoids, saponins, tannins, steroids, phenols and leukoantosians, $A$. scholaris. reported to have various pharmacological activities such as antidiabetic, anti hyperlipidemia, antibacterial, antioxidant, anticancer, anti-inflammatory, analgesic, immunostimulant, antitussive, antiinflammatory, hepatoprotective, antidepressant and antidiarrheal (Pankti et al. 2012; Wang et al. 2017). With the current LC/LR/lc conservation status, it is necessary to regulate and limit the exploration and exploitation of $A$. scholaris for preventing conservation status increase to near threatened or even become vulnerable. Moreover, Large-scale exploitation of a plant without being balanced with any cultivation and conservation programs will just remain several problems related to the sustainability and availability of these plants (Sharma 2017).

In conclusion, the large number of medicinal plants cited by traditional healers showed valuable local knowledge in To Manui ethnic. The results showed that 89 species of medicinal plants distributed in 50 families and 80 genera had been utilized by traditional healers in To Manui ethnic for therapeutic uses to treating 37 types of ailments and diseases whereas tumor/cancer (13.02\%) was the most commonly treated. The most widely used medicinal plant by traditional healers was $C$. longa with the use-value index as of 1.6 and the percentage of use as of $5.41 \%$. Leaf $(54.1 \%)$ was recognized as the most widely used plant part by traditional healers. Asteraceae, Acanthaceae, Anacardiaceae, Euphorbiaceae, Apocynaceae, Arecaceae, Bignoniaceae, Cyperaceae, Davalliaceae, and Lamiaceae were reported to be the ten leading families of plants used by traditional healers. Further investigations on determining the chemical compositions and proving any pharmacological activities of each species need to be programmed in order to provide the scientific database as an alternative for developing safe and effective new therapeutic agents.

\section{ACKNOWLEDGEMENTS}

Our gratitude goes to all traditional healers and Ristoja teams of Indonesian Ministry of Health for carrying out data collection especially in To Manui ethnic, Central Sulawesi, Indonesia and MPTMRDC for conducting Ristoja.

\section{REFERENCES}

Agbor AM, Naidoo S. 2016. A review of the role of African traditional medicine in the management of oral disease. Afr $\mathrm{J}$ Tradit Complement Altern Med 2 13: 133-142.

Ahmed HM. 2016. Ethnopharmacobotanical study on the medicinal plants used by herbalists in Sulaymaniyah Province, Kurdistan, Iraq. J Ethnobiol Ethnomed. DOI: 10.1186/s13002-016-0081-3

Aizman RI, Koroshchenko GA, Gajdarova AP, Sakharov AV, Subotyalov MA. 2014. the mechanisms of Curcuma longa rhizome action on glucose metabolism in alloxan-induced rats. Int Ayurvedic Med J 2: 752-760.

Allahyari S, Delazar A, Najafi M. 2014. Evaluation of general toxicity, anti-oxidant activity and effects of Ficus carica leaves extract on ischemia/reperfusion injuries in isolated heart of rat. Adv Pharm Bull 4: 577-582. DOI: $10.5681 / \mathrm{apb} .2014 .085$ 
Amadi BA, Duru MKC, Agomuo EN. 2012. Chemical profiles of leaf stem, root, and flower of Ageratum conyzoides. Pelagia Res Libr Asian J Plant Sci Res 428-432.

Anon. 2015. Indigenous knowledge as a key to sustainable development. DOI: $10.4038 /$ jas.v2i1.8117

Anon. 2017. Kecamatan Menui Kepulauan dalam angka 2017. Morowali District. [Indonesian]

Anon. 2018a. Latest global cancer data: Cancer burden rises to 18.1 million new cases and 9.6 million cancer deaths in 2018

Anon. 2018b. Morowali District in figures 2018. Central Sulawesi. [Indonesian]

Anon. 2019. WHO global report on traditional and complementary medicine 2019

Arnob SY. 2011. Cytotoxic and antioxidant evaluation of methanolic extract of Aglaonema hookerianum.

Awal SMA, Nazmir S, Nasrin S, Nurunnabi TR, Uddin SJ. 2016. Evaluation of pharmacological activity of Hibiscus tiliaceus SpringerPlus. DOI: 10.1186/s40064-016-2891-0

Ayyadurai N, Valarmathy N, Kannan S, Jansirani D, Alsenaidy A. 2013 Evaluation of cytotoxic properties of Curcuma longa and Tagetes erecta on cancer cell line (Hep2). Afr J Pharm Pharmaco 7: 736-739. DOI: $10.5897 / A J P P 12.031$

Ayyanar M, Ignacimuthu S. 2011. Ethnobotanical survey of medicinal plants commonly used by Kani tribals in Tirunelveli hills of Western Ghats, India. J Ethnopharmacol 134: 851-864. DOI 10.1016/j.jep.2011.01.029

Battu PG, Male CKVLSNA, Priya HT, Malleswari VN, Reeshma S. 2011. A phyto pharmacological review on vigna species. Pharmanest 2.

Bello I, Bakkouri AS, Tabana YM, Al-hindi B, Al-mansoub Majed A Mahmud R. Asmawi MZ. 2016. Acute and sub-acute toxicity evaluation of the methanolic extract of Alstonia scholaris stem bark. Med Sci 4: 1-14. DOI: 10.3390/medsci4010004.

Bessada SMF, Barreira JCM, Beatriz M, Oliveira PP. 2015. Asteraceae species with most prominent bioactivity and their potential applications: A review. Ind Crops Prod 76: 604-615. DOI: 10.1016/j.indcrop.2015.07.073

Bettio LEB, Machado DG, Cunha MP, Capra JC, Missau FC, Santos ARS, Pizzolatti MG, S AL, Bettio LEB, Machado DG, Cunha MP Capra JC, Missau FC. 2011. Antidepressant-like effect of extract from Polygala paniculata: Involvement of the monoaminergic systems. Pharm Biol 49: 1277-1285. DOI: 10.3109/13880209.2011.621958

Bezerra JWA, Costa AR, Silva MAP, Rocha MI, Boligon AA, Rocha JBT, Barros LM, Kamdem JP. 2017. Chemical composition and toxicological evaluation of Hyptis suaveolens (L.) Poiteau (Lamiaceae) in Drosophila melanogaster and Artemia salina. South Afr J Bot 113: 437-442. DOI: 10.1016/j.sajb.2017.10.003

Bopda OSM, Longo F, Boade F, Dzeufiet PDD, Dimo T. 2016. Subchronic toxicity of the leaf aqueous extract of Bidens pilosa Linn (Asteraceae) in male and female rats. J Med Plants Res 10: 676-685. DOI: $10.5897 /$ JMPR2016.6242

Caetano CP, Fonseca M, Fernandes C, Regina E, Pereira S. 2017. Neurotoxicity following the ingestion of Bilimbi fruit (Averrhoa bilimbi) in an end-stage renal disease patient on hemodialysis. Case Rep Nephrol Dial 7: 6-12. DOI: 10.1159/000454945

Caparroz-assef SM, Grespan R, Coelho R, Batista F, Bersani-amado FA, Baroni S, Dantas JA, Cuman KN, Bersani-amado CA. 2005. Toxicity studies of Cordia salicifolia extract. 41-44.

Chang CJ, Tzeng T, Liou S, Chang Y, Liu I. 2012. Acute and 28-day subchronic oral toxicity of an ethanol extract of Zingiber zerumbet (L.) Smith in rodents. Evidence-Based Complement Altern Med 1-11 DOI: $10.1155 / 2012 / 608284$

Chivapat S, Bunjob M, Shuaoprom A, Bansidhi J, Chavalittumrong P, Rangsripipat A, Sincharoenpokai P. 2011. Original report chronic toxicity of Passiflora foetida L. extract. Int J Appl Res Nat Prod 4: 24-31.

Chunlaratthanaphorn S, Lertprasertsuke N, Srisawat U, Thuppia A, Ngamjariyawat A, Suwanlikhid N, Jaijoy K. 2007. Acute and subchronic toxicity study of the water extract from root of Citrus aurantifolia ( Christm.et Panz.) Swingle in rats. J Sci Technol 29: 125-139.

Chunlaratthanaphorn S, Lertprasertsuke N, Srisawat U, Thuppia A Ngamjariyawat A, Suwanlikhid N, Jaijoy K. 2014. Acute and subchronic toxicity study of the water extract from root of Imperata cylindrica (Linn.) Rausch. in rats. J Sci Technol 29: 141-155.

Coria-Tellez A V, Montalvo-Gonzales E, Yahia EM, Obledo-Vazquez EN. 2018. Annona muricata: A comprehensive review on its traditional medicinal uses, phytochemicals, pharmacological activities, mechanisms of action and toxicity. Arabian J Chem 11: 662-691. DOI: $10.1016 /$ j. arabjc. 2016.01 .004

Dhal NK, Panda SS, Muduli SD. 2015. Traditional uses of medicinal plants by native people in Nawarangpur district, Odisha, India. Pelagia Res Libr Asian J Plant Sci Res 5: 27-33.

Diallo A, Eklu-gadegkeku K, Agbanon A, Aklikokou K, Creppy EE, Gbeassor M. 2010a. Acute and sub-chronic (28-day) oral toxicity studies of hydroalcoholic leaf extract of Ageratum conyzoides L (Asteraceae ). Trop J Pharm Res 9: 463-467.

Diallo A, Eklu-Gadegkeku K, Agbanon A, Aklikokou K, Creppy E, Gbeassor M. 2010b. Lannea coromandelic.pdf. J Pharmacol Toxicol 5: 343-349.

Diniz M de FFM, Pessoa H de LF, Sa CB de, Lira AB, Ramalho L da SN, de Oliveira kardilandia M, Dias GT, Melo CR, Ramalho J do A, Lima CMBL. 2018. Non-clinical acute and chronic toxicity evaluations of Cissus sicyoides L. (Vitaceae) hydroalcoholic leaf extract. Toxicol Rep 5: 890-896. DOI: 10.1016/j.toxrep.2018.07.001

Du G, Xiao M, Yu S, Wang M, Xie Y, Sang S. 2018. Phyllanthus urinaria: a potential phytopharmacological source of natural medicine. Int J Clin Exp Med 11: 6509-6520.

Dutta S, Bhattacharyya D. 2013. Enzymatic, antimicrobial and toxicity studies of the aqueous extract of Ananas comosus (pineapple) crown leaf. J Ethnopharmacol: 1-7. DOI: 10.1016/j.jep.2013.08.024

Fuentes-Leon F, Gonzalez-Pumariega M, Tamayo MV, Menchk CFM, Sanchez-Lamar A. 2017. Toxic evaluation of Cymbopogon citratus chemical fractions in E.coli. Cosmetics 4: 1-22. DOI: 10.3390/cosmetics4020020

Gadelha ICN, Fonseca NBS, Oloris SCS, Melo MM, Soto-blanco B. 2014. Gossypol toxicity from cottonseed products. 2014: 4-6.

Gahlot K, Abid M, Lal VK, Jha S. 2013. Sedative and anticonvulsant activities of the ethanol root extract of Flemingia chappar Benth 12: 203-208.

Gamallo JPM, Gallego RP. 2017. Evaluation of antiangiogenic property and toxicity of Ficus septica Burm F. stem extracts. Proceedings of RF-ISERD: 11-17.

Ha AW, Kang HJ, Kim SL, Kim MH, Kim WK. 2018. Acute and subacute toxicity evaluation of corn silk extract. Prev Nutr Food Sci 23: 70-76.

Hamidpour R, Hamidpour S, Hamidpour M, Sohraby M, Hamidpour R. Turmeric (Curcuma longa): from a variety of traditional medicinal applications to its novel roles as active antioxidant, antiinflammatory, anti-cancer, and anti-diabetes. DOI: 10.18052/www.scipress.com/IJPPE.1.37

Harahap U, Marianne, Agustya HM, Azizah DU, Alfiah SW. 2018. Subchronic toxicity evaluation of ethanol extract of picria fel-terrae lour. leaf in Wistar rats. Sci Pharm 86: 1-9. DOI: 10.3390/scipharm86030034

Hilmarni, Yohana Y, Rosi DH. 2016. Uji toksisitas ekstrak daun ungu (Graptophyllum pictum) terhadap profil hematologi mencit putih. 113. [Indonesian]

Huang L, Lei T, Lin C, Kuang X, Chen H, Zhou H. 2010. Blumeaxanthene II, a novel xanthene from Blumea riparia DC. Fitoterapia 81: 389-392. DOI: 10.1016/j.fitote.2009.11.009

Idang EO, Udom GJ, Ogbuagu EO, John UA. 2019. Toxicology digest toxicological assessment of Zingiber officinale Roscoe (Ginger) root oil. Toxicol Digest 4: 108-119.

Igbe I, Innih S, Ogedengbe SV, Amamina L. 2015. Toxicity studies of aqueous leaf extract of Voacanga africana in Wistar rats. J Appl Sci Environ Manag 19: 639-646.

Iskandar I, Setiawan F, Sasongko LDN, Adnyana IK. 2017. Six-month chronic toxicity study of tamarind pulp (Tamarindus indica L.) water extract. Sci Pharma 85: 1-10. DOI: $10.3390 /$ scipharm 85010010

JE A, Odia E, Omogbai E, Amaechina F, AO A, LE E. 2006. Histopathologic effects of Stachytarpheta jamaicensis (L.) Vahl on Wistar rats. Pak J Biol Sci 9: 477-482.

Kafle A, Mohapatra SS, Reddy I. 2018. A brief review on toxicity of Abrus precatorius in animals. J Entomol Zool Stud 6: 1102-1104.

Karthiyayini R. 2012. Medicinal plant leaves used by local practitioners of Coimbatore District, Tamil Nadu, India. Int J Pharma Sci Res 3: 1829-1831.

Karunarathne P, Thammitiyagodage M, Weerakkody N. 2018. Safety evaluation of galangal (Alpinia galanga) extract for therapeutic use as an antimicrobial agent. Int J Pharm Sci Res 9: 4582-4590. DOI: 10.13040/IJPSR.0975-8232.9(11).4582-90 
Khan A, Rahman M, Islam MS. 2008. Neuropharmacological effects of Peperomia pellucida leaves in mice. 16: 35-40.

Krishna U, Nayak RP, Chaitra SR. 2019. Original Research Article Preclinical evaluation of antidepressant activity of aqueous extract of Piper betle leaves in Swiss albino mice. IJBCP Int J Basic Clin Pharmacol 8: 143-146.

Kurapati KR V, Samikkannu T. 2012. Combinatorial cytotoxic effects of Curcuma longa and Zingiber officinale on the PC-3M prostate cancer cell line Combinatorial cytotoxic effects of Curcuma longa and Zingiber officinale on the $\mathrm{PC}-3 \mathrm{M}$ prostate cancer cell line. DOI 10.1515/jbcpp-2012-0021

Mabel Y, Simbala H, Koneri R. 2016. Identifikasi dan pemanfaatan tumbuhan obat suku Dani di Kabupaten Jayawijaya Papua. J Mipa Unsrat Online 5: 103-107. [Indonesian]

Mahajon B. 2019. Preliminary analysis of botanical and phytochemical features of kamalu-Homeopathy \& Ayurvedic Medicine Preliminary Analysis of Botanical and Phytochemical Features of Kamalu-. DOI: 10.4172/2167-1206.1000171

Manuel B, Muller R. 2013. Protecting shared traditional knowledge.

Masudur RDS, Nurul Amin M, Adnan T, Naim Uddin S, Shahid-UdDaula A, Sarwar G, Shohel Hossain M. 2013. Investigation of analgesic potential and in vitro antioxidant activity of two plants of Asteraceae family growing in Bangladesh. JOPR: J Pharm Res 6: 599-603. DOI: 10.1016/j.jopr.2013.05.016

Mayo S, Gardens RB, Andrade IM, Ministro C, Velloso R. 2015. Ethnobotanical survey of medicinal plants used by the community of Sobradinho, Luís Correia, Piauí, Brazil. DOI 10.5897/JMPR2015.5881

Megersa M, Jima TT, Goro KK. 2019. The Use of medicinal plants for the treatment of toothache in Ethiopia.

Mohammed A. 2017. Hypoglycemic activity of Curcuma longa Linn roo extracts on alloxan-induced diabetic rats. DOI 10.21276/haya.2017.2.2.4

Musa MS, Abdelrasool FE, Elsheikh EA, Ahmed LAMN, Mahmoud ALE, Yagi SM. 2011. Ethnobotanical study of medicinal plants in the Blue Nile State, South-eastern Sudan. 5: 4287-4297.

Mustofa FI, Rahmawati N. 2018. Studi etnofarmakologi tumbuhan obat yang digunakan oleh penyehat tradisional untuk mengatasi diare di Sulawesi Selatan. 11: 17-32. [Indonesian]

Nagarjuna R V, Krishna GJ, Rao VK, Balaji CH, Prabhudeva M, Kumar AR, Reddy AJR, Vallabh V. 2015. Toxicity studies of extract of Morinda citrifolia. Int J Pharm Chem Biol Sci 5: 141-145.

Ngarivhume T, Van'T Klooster CIEA, De Jong JTVM, Van De Westhuizen JH. 2015. Medicinal plants used by traditional healers for the treatment of malaria in the Chipinge district in Zimbabwe. J Ethnopharmacol 159: 224-237. DOI: 10.1016/j.jep.2014.11.011

Nisah K. 2017. Uji toksisitas dari penyalut layak makan berbasis pati (Metroxylon sagu). J Biotik 5: 66-71. [Indonesian]

Ogbalu O, Williams J. 2014. The use of Ageratum conyzoides L. (Asteraceae) as a therapeutic measure in the treatment of breast myiasis sores in rural women and associated bacteria. IOSR J Pharm Biol Sci 9: 44-50

Olatunde A, E.B. J, H., Tijjani OSM, C.D. L. 2014. Anti-diabetic activity of aqueous extract of Curcuma longa (Linn) rhizome in normal and alloxan-induced diabetic rats. Researcher 6: 58-65.

Olayemi AT, Olanrewaju MJ, Oloruntoba AC. 2016. Toxicologica evaluation of Moringa oleifera Lam seeds and leaves in Wistar rats. 6: $100-111$

Olowolafe T, Mo O. 2018. Toxicity of aqueous extracts of bitter leaf (Vernonia amygdalina) on hematological profile of African catfish (Clarias gariepinus) juveniles. Int J Fish Aquat Stud 6: 596-600.

Omonkhua AA, Onoagbe I. 2011. Evaluation of the long-term effects of Urena lobata root extracts on blood glucose and hepatic function of normal rabbits. J Toxicol Environ Health Sci 3: 204-213.

Omorodion NT, Ajanwachuku WO. 2018. Investigation of histopathological effect of Piper nigrum consumption on selected organs of male Wistar rats. Acta Sci Nutr Health 2: 3-7.

Ozolua RI, Idogum SE, Tafamel GE. 2010. Acute and sub-acute toxicological assessment of aqueous leaf extract of Bryophyllum pinnatum ( Lam.) in Sprague-Dawley Rats Raymond Iduojemu Ozolua, 2 Sylvester Eshiotseme Idogun and 1 Glory Eshiagiamhe Tafamel Department of Pharmacology and Toxicology. Am J Pharmacol Toxicol 5: 145-151.

Padhy R, Patro SK, Jena M, Dash SK. 2017. Toxicity evaluation of methanolic rhizome extracts obtained from Drynaria quercifolia
Linn.) J. Smith in experimental animals. : 255-258 DOI: 10.21276/haya.2017.2.7.4

Pankti K, Payal G, Manodeep C, Jagadish K. 2012. A phytopharmacological review of Alstonia scholaris: A panoramic herbal medicine. Int J Res Ayurveda Pharm 3: 367-371.

Paul N, Roy R, Bhattacharya S, Biswas M. 2012. Acute and sub-chronic toxicity study of Cocos nucifera leaf extracts in mice. 2: 74-81.

Paulose P, Juliet S, Sujith S, Sini M, Divya TM, Nair SN, Chandrasekhar L, Pradeep M, George AJ, Ravindran R. 2016. Evaluation of toxicological potential of Chromolaena odorata found in the Western Ghats of Indian Subcontinent orally in mice. Adv Anim Vet Sci 4: 7884.

Perk BO, Ilgin S, Atli O, Duymus HG, Sirmagul B. 2013. Acute and subchronic toxic effects of the fruits of Physalis peruviana L. evidence-based complementary and alternative medicine 1-10. DOI: 10.1155/2013/707285

Ping KY, Darah I, Chen Y, Sreeramanan S, Sasidharan S. 2013. Acute and subchronic toxicity study of Euphorbia hirta L. methanol extract in rats. BioMed Res Int 2013.

Pour BM, Sasidharan S. 2011. In vivo toxicity study of Lantana camara. Asian Pac J Trop Biomed 1: 28-31. DOI: 10.1016/S22211691(11)60033-6

Rachmawati E, Ulfa EU. 2018. Uji toksisitas subkronik ekstrak kayu kuning (Arcangelisia flava Merr) terhadap hepar dan ginjal. Glob Med Health Commun 6: 1-6.

Rafieian-Kopaei M, Nasri H, Sahinfard N, Rafieian M, Rafieian S, Shirzad M. 2014. A spice with multifunctional medicinal properties. J HerbMed Pharmacol Turmeric.

Rahman A, Imran T Bin, Islam S. 2013. Antioxidative, antimicrobial and cytotoxic effects of the phenolics of Leea indica leaf extract. Saudi J Biol Sci 20: 213-225. DOI: 10.1016/j.sjbs.2012.11.007

Rahman NAA, Fazilah A, Effarizah ME. 2015. Toxicity of nutmeg (myristicin): a review. Int J Adv Sci Eng Inf Technol 5: 212-215.

Rahman SMM, Islam N, Ahammad F, Islam S, Saha B, Rahman H. 2019. Anti-inflammatory, antinociceptive and antidiarrhoeal activities of methanol and ethyl acetate extract of Hemigraphis alternata leaves in mice. DOI: 10.1186/s40816-019-0110-6

Reddy C V, Kamble A. 2017. Toxicity study of Achyranthus aspera. Int Lett Nat Sci 14. DOI: 10.18052/www.scipress.com/ILNS.14.85

Riris ID, Simorangkir M, Silalahi A. 2018. Antioxidant, toxicity and antibacterial properties of ompu-ompu (Crinum asiaticum L) ethanol extract. Rasayan J Chem 11: 1229-1235. DOI: 10.31788/RJC.2018.1133090

Sagrin MS, Lasano NF, Shukri R, Ramli NS. 2019. Antioxidant properties and toxicity assessment of the Crescentia cujete extracts in brine shrimp (Artemia salina). Sains Malays 48: 831-840. DOI: 10.17576/jsm-2019-4804-15

Sambara J, Nyoman Yuliani N, Yuniati Emerensiana M. 2016. Pemanfaatan tanaman obat tradisional oleh masyarakat Kelurahan Merdeka Kecamatan Kupang Timur 2016. Jurnal Info Kesehatan 14. [Indonesian]

Santi I, Nurbaezurah S. 2013. Uji toksisitas fraksi n-butanol beruwas laut (Scaveola taccada (Gaertn.) Roxb.) dengan metode Brine Shrimp Lethality Test. As-Syifaa 05: 88-94. [Indonesian]

Schmidt E, Ryabchenko B, Wanner J, Jager W, Jirovetz L. 2015. Cytotoxic active constituents of essential oils of Curcuma longa and Curcuma zanthorrhiza. Nat Prod Commun 10: 139-141. DOI: $10.1177 / 1934578 \times 1501000132$

Sciences B, Alam MS, Hossain MB, Nesa MN, Rahman MM, Extension A. 2008. Study of species diversity on the family Asteraceae ( Compositae) of the Rajshahi Division 4: 794-797.

Sequete FR, Nuneza OM, Mylene MU. 2016. Evaluation of toxicity of the bioactive components from the stem of Buyo (Piper betle L.) extracts. Exp Find 1-9. DOI: 10.13140/RG.2.2.34662.83527

Shah V. 2010. Five cases of Jatropha curcas poisoning.

Sharma A. 2017. India as the heritage of medicinal plant and their use. Curr Trends Biomed Eng Biosci 4. DOI: 10.19080/CTBEB.2017.04.555641

Shukla D, Shah K, Rawal R, Jain N. 2016. Anticancer and cytotoxic potential of turmeric (Curcuma longa), neem (Azadirachta indica), tulasi (Ocimum sanctum) and ginger (Zingiber officinale) extracts on $\mathrm{HeLa}$ cell line. Int J Life Sci Scienti Res 2: 309-315. DOI: 10.21276/ijlssr.2016.2.4.2

Simaremare ES, Holle E, Gunawan E, Yabansabra YR, Octavia F, Pratiwi RD. 2018. Toxicity, antioxidant, analgesic and anti-inflammatory of 
ethanol extracts of Laportea aestuans ( Linn.) Chew. J Chem Pharm Res 10: 16-23.

Singh T, Singh A, Kumar R, Singh JK. 2016. Acute toxicity study of Phyllanthus niruri and its effect on the cytoarchitectural structure of nephrocytes in Swiss albino mice. Pharmacognosy J 8: 77-80.

Sireeratawong S, Lertprasertsuke N, Srisawat U, Thuppia A. 2008. Acute and subchronic toxicity study of the water extract from root of Sida rhombifolia Linn. in rats. Songklanakarin J Sci Technol 30: 729-737.

Sittisomwong N, Leelasangaluk V, Chivapat S, Wangmad A, Ragsaman V, Chuntarachaya C. Acute and subchronic toxicity of turmeric. 32 101-111.

Specht JKCD, Konig BJ, Ginger M, Flag S, Ginger S. 2014. Cheilocostu speciosus. 7: 712-725. DOI: 10.1007/978-94-007-7395-0

Subositi D, Wahyono S. 2019. Study of the genus Curcuma in Indonesia used as traditional herbal medicines. 20: 1356-1361. DOI 10.13057/biodiv/d200527

Sumiwi SA, Zuhrotun A, Hendriani R, Rizal M, Levita J, Megantara S. 2019. Subchronic toxicity of ethanol extract of Syzygium polyanthum (Wight) Walp. leaves on Wistar rat. Indones Biomed J 11: 30-35. DOI: $10.18585 /$ inabj.v11i1.458

Tambaru E. 2016. Jenis-jenis tumbuhan dicotyledoneae berpotensi obat dimanfaatkan oleh masyarakat di cagar alam Karaenta Bantimurung Bulusaurung Kabupaten Maros. Prosiding Seminar Nasional from Basic Science to Comprehensive Education. Makassar, 146-150. [Indonesian]

Tarkang PA, Agbor GA, Armelle TD, Yamthe LR, David K, Ngadena YSM. 2012. Acute and chronic toxicity studies of the aqueous and ethanol leaf extracts of Carica papaya Linn in Wistar rats. J Nat Prod Plant Resour 2: 617-627.

Town S. 2018. Assessment of traditional practices of healers to treat human illness in internal medicine. DOI: 10.4172/2165 8048.1000278
Ugbogu EA, Ude VC, Elekwa I, Okuu U. 2018. Toxicological profile of the aqueous-fermented extract of Musa paradisiaca in rats toxicological profile of the aqueous-fermented extract of Musa paradisiaca in rats.

Utami ED, Baroroh HN, Nuryanti. 2018. Subacute toxicity effect of ethanolic extract of Psidium guajava leaves on gaster in Wistar rat. J Ilmu Kefarmasian Indonesia 16: 61-66. [Indonesian]

Verma M, Raj PV, Chandrasekhar HR, Rao JV, Udupa N. 2009. Screening of plant Macaranga peltata for its antioxidant, antimicrobial and cytotoxicity activity. IEEE: 1-27. DOI: 10.1109/ICBPE.2009.5384086

Wang CM, Yeh KL, Tsai SJ, Jhan YL, Chou CH. 2017. Anti-proliferative activity of triterpenoids and sterols isolated from Alstonia scholaris against non-small-cell lung carcinoma cells. Molecules 22: 1-13. DOI: $10.3390 /$ molecules 22122119

Wattanathorn J, Wannanon P, Muchimapura S, Thukham-mee W, Tongun T, Polyiam P. 2019. Toxicity evaluation of Anacardium occidentale, the potential aphrodisiac herb. Biomed Res Int 2019: 120.

Yehya AHS, Asif M, Kaur G, Hassan LEA, Al-suede FSR, Abdul AMS, Oon CE. 2019. Toxicological studies of Orthosiphon stamineus ( Misai Kucing ) standardized ethanol extract in combination with gemcitabine in athymic nude mice model. J Adv Res 15: 59-68. DOI: 10.1016/j.jare.2018.05.006

Yulia C, Fahri, Pitopang R. 2017. Studi etnobotani tumbuhan obat Suku "Topo Uma" di Desa Oo Parese Kecamatan Kulawi Selatan Kabupaten Sigi Sulawesi Tengah. Biocelebes 12: 1-22. [Indonesian]

Yunus K, Jaafar AM, John A. 2019. Acute-lethal toxicity (LC 50) effect of Terminalia catappa Linn. leaves extract on Oreochromis niloticus (red nile tilapia) juveniles under static toxicity exposure. Orient $\mathbf{J}$ Chem 35: 270-274.

Zhang Q, Africa I. 2018. Policy Review. 1: 11-13. DOI: $10.1142 / \mathrm{S} 257590001820001 \mathrm{X}$ 


\section{BIODIVERSITAS}

ISSN: 1412-033X

Volume 21, Number 1, January 2020

E-ISSN: 2085-4722

Pages: 375-392 